Article

\title{
COMPARATIVE STUDY OF THERMAL COMFORT INDICES: A MELBOURNE CBD CASE STUDY
}

\author{
A.W.M Ng ${ }^{1,2^{*}}$, Nitin Muttil ${ }^{12^{*}}$, Fatma Balany ${ }^{1}$, Bruke Zegeye $^{1}$ \\ ${ }^{1}$ College of Engineering and Science, Victoria University, PO Box 14428, Melbourne VIC 8001, Australia \\ ${ }^{2}$ Institute for Sustainable Industries \& Liveable Cities, Victoria University, PO Box 14428 Melbourne VIC 8001, \\ Australia \\ *Correspondence: anne.ng@vu.edu.au (A.N.); nitin.muttil@vu.edu.au (N.M.)
}

\begin{abstract}
This study assesses Human Thermal Comfort in two selected areas: a Green Infrastructure (GI) area represented by a garden and a high-rise building area, in the Central Business District (CBD) of Melbourne, Australia. Three-dimensional microclimatic modelling software, ENVI-met version 4 was used to simulate the microclimate. The indices of Predicted Mean Vote (PMV), Physiological Equivalent Temperature (PET) and Universal Temperature Climate Index (UTCI) were used to quantify the level of thermal comfort in the research areas. The simulation results showed that at midday, the difference in temperature between the garden area and the high-rise building area was approximately $1^{\circ} \mathrm{C}$. Increasing temperatures at midday led to a change in the level of thermal comfort for both the areas, even though it was not significant. In general, the thermal perception in the GI area was slightly 'cooler' than in the high-rise building area. The results of the study indicated the important role of GI in improving the thermal comfort in urban areas.
\end{abstract}

Key words: Green Infrastructure (GI), Human Thermal Comfort (HTC), ENVI-met, microclimate, modelling.

\section{Introduction}

An increase in population is becoming a major problem in many urban areas around the world. The Urban Heat Island (UHI) phenomenon is one of the well-known consequences of increasing population [1, 2]. In order to combat UHI, Green-Infrastructure (GI) has been introduced in some cities across the globe as a mitigation strategy to reduce temperature and improve Human Thermal Comfort (HTC) [3-11]. HTC is the condition of mind that expresses satisfaction with the thermal environment and is assessed by subjective evaluation (ASHRAE). Many studies have been conducted to evaluate the level of thermal comfort inside and outside buildings [12-23]. More than 100 indices have been developed [24] some of which are commonly used in thermal comfort studies [25], including Predicted Mean Vote (PMV) [26], Physiological Equivalent Temperature (PET) [27], Universal Thermal Climate Index (UTCI) [28-30] and Standard Effective Temperature (SET) [31]. PMV describes the extent of warm and cool sensation in seven scales (+3 to -3). The PMV method, developed in 1970, is based on a heat balance model. It combines four physical variables (air temperature, air velocity, mean radiant temperature, and relative humidity), and two personal variables (clothing insulation and activity level) in an index that can be used to predict the average thermal sensation of a large group of people. This index is regarded as more sensitive than other thermal comfort indices [32]. Like PMV, PET have been derived from the output of human energy balance model Munich Energy-balance Model for Individual (MEMI). The index is one of the most commonly used in thermal comfort studies, especially for outdoor setting [16, 25, 33]. Meanwhile UTCI is regarded as one of the most comprehensive indices for calculating outdoor heat stress level [34]. In this study, PMV, PET and UTCI were used to evaluate the thermal comfort condition of the areas researched. 
Study about vegetation has been extensively conducted. Vegetation regulates microclimate (a local set of atmospheric conditions that differ from those in the surrounding areas) through shading and evapotranspiration. Shading reduces ambient air temperature by blocking solar radiation, therefore restricting the increase in air temperature as well as the temperature of ground surfaces. Evapotranspiration refers to transpiration from plants and evaporation from water bodies and soils. The absorbed solar energy is converted into the latent heat of evaporation; thus the temperature of surrounding area will be cooled. Several studies in urban gardens have been conducted. The studies showed that gardens commonly have cooler temperatures than their surrounding areas [35-37]. Meanwhile, materials commonly found in urban area include concrete, asphalt, tile, and glass. One of the important characteristics of these materials is their albedo value which is related to their colour. High-albedo materials can save cooling energy use by directly reducing the heat gain through a building's envelope (direct effect) and also by lowering the urban air temperature in its neighbourhood (indirect effect). Concrete and asphalt which are usually dark coloured, are known as materials with low albedo (absorptive or materials that do not reflect a considerable amount of direct solar radiation); hence it can intensify the UHI. In addition, areas with dense buildings (with little open space) have the capability to trap heat; thus they potentially increase temperatures and eventually increase the level of heat stress.

Recently, Melbourne has experienced rapid population growth, a process in which land use, urban form and ground cover changes. Melbourne recorded the largest - and fastest - growth of any Australian capital city in 2016-2017 (https://planmelbourne.vic.gov.au). The Melbourne Central Business District (CBD) has become the most populated area in Melbourne and has warmer temperature than other part of the city. Given the rise in air temperature in the CBD, this research aims to quantify the difference between GI and building area in terms of microclimate and human thermal comfort by taking two locations in the Melbourne CBD. For that purpose, the ENVI-met model [38] was utilised to simulate a microclimate and calculate the thermal sensation on the areas. The research analysed the effect of GI on outdoor HTC which leads to the minimization of the UHI effect in the city of Melbourne.

The paper is organized as follows: Section 2 describes the methodology including field measurements and numerical simulation, Section 3 presents the results, followed by discussion in Section 4 . The conclusions and recommendations for future research are finally presented in Section 5.

\section{Methodology}

The aim of this research was to study thermal comfort conditions in both a GI and a building area by conducting simulations. Recently, modelling software has been developed to simulate vegetation, urban structure and microclimate interaction. One of the most widely used is ENVI-met which can simulate microclimate and calculate HTC in an urban environment. The model utilizes its own realistic interface to plot the design of the area, and its own editorial editing tools for climatic information, plants, soils and sources databases. The outputs of the model are basic 3D data on environment, surface and motion and soils [39]. Field measurement was conducted to collect data for model validation. Numerical simulation was performed on 20 May 2020 and ran for 24 hours with time steps of one hour.

\subsection{Study Area}

Melbourne $\left(37.8^{\circ} \mathrm{S}, 144.9^{\circ} \mathrm{E}\right)$ is in the south eastern part of Australia, within the state of Victoria (Figure 1). The city is known for its gardens, tree-lined streets and floral displays. According to the Koppen climate classification, Melbourne is classified as a temperate oceanic climate with warm to hot summers and mild winters. Summer usually begins in December while winter starts in June. The highest temperature ever recorded during summer time in the city was $46.4{ }^{\circ} \mathrm{C}$ and the lowest was -2.8 ${ }^{\circ} \mathrm{C}$. 


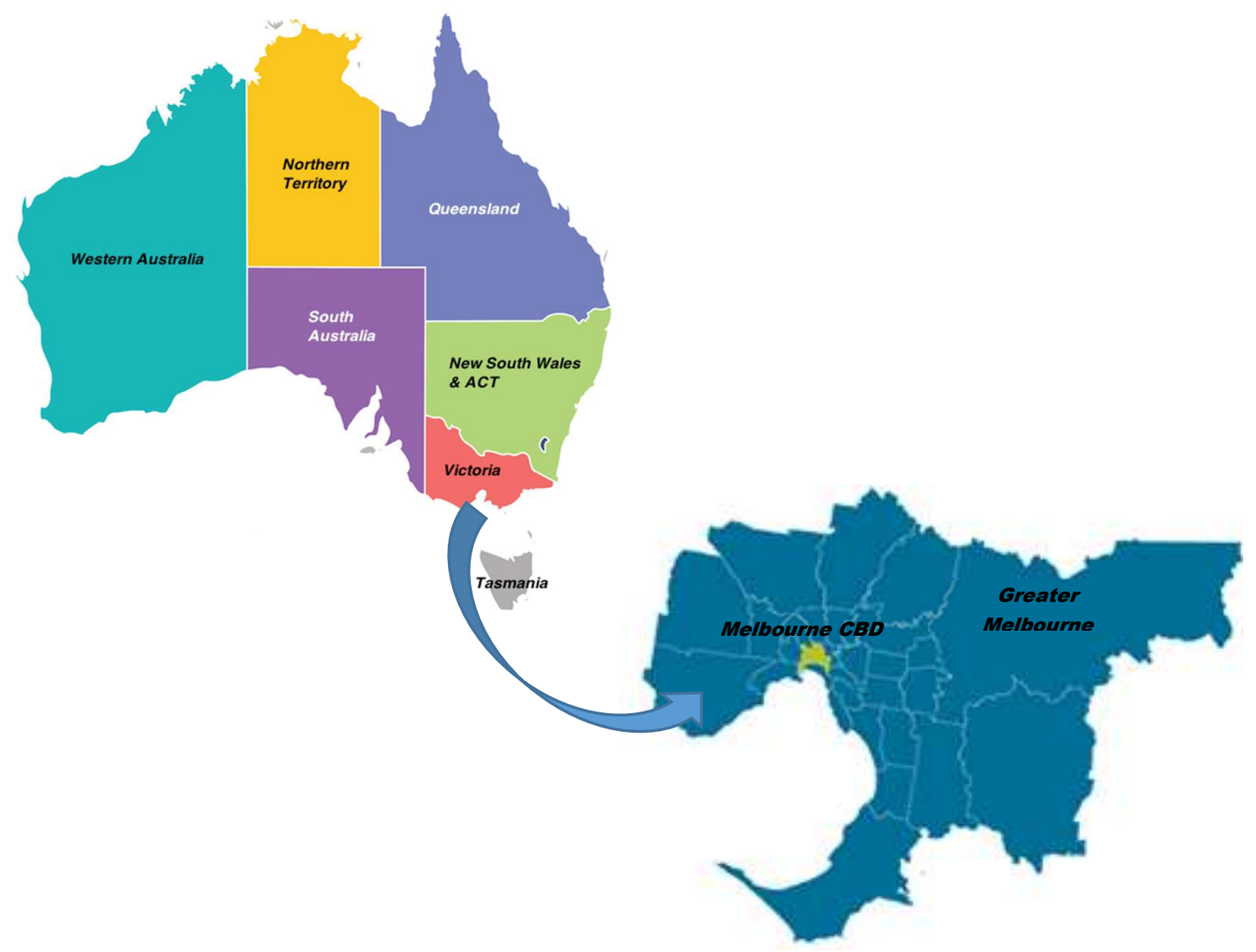

Figure 1. Melbourne Victoria, Australia

Melbourne CBD is characterised by spacious, tree-lined streets, with many tram lines and highrise buildings. Areas around the Treasury Gardens and the Ibis Melbourne Hotel and Apartments were selected for this study. Both are located in the Melbourne CBD. The Treasury Gardens are an urban garden located on the south-eastern side of the city. It is bounded by Wellington Parade, Spring Street, and Treasury Place and by the Fitzroy Gardens across Lansdowne Street. The common residents in these gardens are possums, birds and bugs; therefore there is less contribution of negative impact from human (Figure 2a). The second area selected for the study was the Ibis Melbourne Hotel and Apartments situated near the Queen Victoria market close to Elizabeth and Victoria Street. This area has a high population and built density, as it is surrounded by tall buildings (Figure 2b).




Figure 2. Research areas: (a) The Treasury Gardens (b) The Ibis Melbourne Hotel and Apartments

\subsection{Field Measurements}

Field measurements were performed in both research areas on several days in May 2020. The instrument used was a HOBO MX2301A data logger (https://www.hobodataloggers.com.au/mx2301A). To collect data, one area in the gardens and around the Ibis Melbourne were selected. The instrument was set up in a safe spot in each area and secured against wind gusts in order to assess their climate. The HOBO MX2301A was utilised to quantify relative humidity and ambient temperature for each area. The data logger was pre-modified to record the information continuously every 10 minutes. Climatic data such as air temperature, relative humidity, and wind speed and direction were retrieved from Bureau of Meteorology (BoM) Australia and used as input data sets.

\subsection{Microclimate modelling}

ENVI-met is a three-dimensional non-hydrostatic microclimate model designed to analyse interaction between microclimate and urban design on a micro scale. The model computes the elements of microclimate during a diurnal cycle utilizing the principal laws of fluid dynamics and thermodynamics such as wind speed and direction, air temperature, humidity, radiative fluxes and pollutant dispersion [40]. Two input data sets are required for ENVI-met simulation, namely an input file and a main configuration file. Input file data is needed to build the spatial properties of the research area such as geographical location, the height and material of the buildings, the type of soil and surface and vegetation with an average grid resolution of 0.5 to 10 meters in space. The main configuration file contains initial meteorology values such as air temperature, relative humidity, wind speed and direction necessary for simulation. For the purpose of this study, two research areas were set at $60 \mathrm{~m}$ wide and $30 \mathrm{~m}$ high with the size of the grid $2 \mathrm{~m}$ and $4 \mathrm{~m}$ for $\mathrm{z}$ direction. Given high rise buildings in the Ibis Melbourne Hotel and Apartments area, the telescoping factor was activated at 20\%. In this research the London plane tree (Platanus $x$ Acerifolia) and grass were modelled. The selected plants were appropriate options for the model area because they are commonly found in the Melbourne CBD, including in the Treasury Gardens. Table 1 shows a setting for the configuration file that was used to run the initial ENVI-met model for the two designated areas.

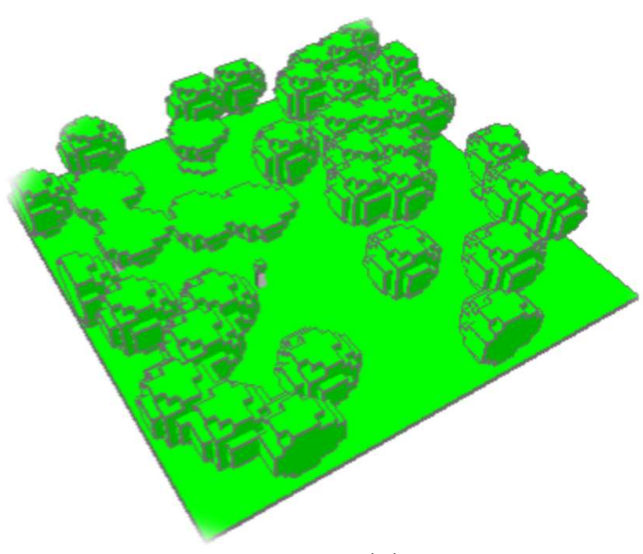

(a)

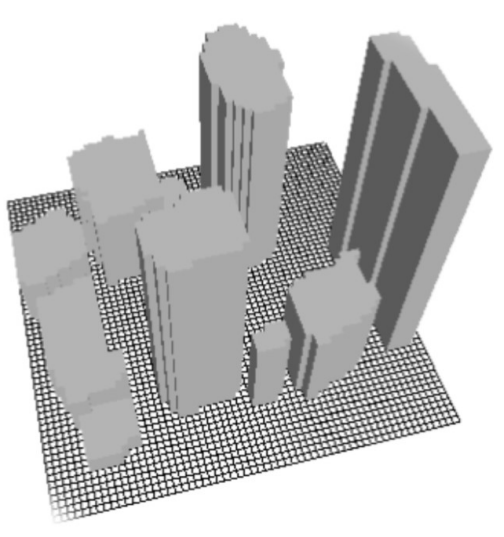

(b)

Figure 3. Digitized research areas: (a) The Treasury Gardens (b) The Ibis Melbourne Hotel and Apartments 
The ENVI-met guide was used for simulation and the Leonardo tool was used for deduction and data analysis. The garden and the building area were simulated for 24 hours. ENVI-met BioMet is a post-processing tool to calculate human thermal comfort indices. The tool directly interacts with ENVI-met output to generate a thermal comfort index without running ENVI-met again. The tool needs climatic and personal parameters as an input. While climatic parameters are based on simulation results, personal parameters such as gender, weight, height, and level of activity can be customised. The PMV, PET and UTCI indices were used to measure the level of thermal comfort. PMV is a measurement utilised to estimate the mean value of votes of people on a seven-point thermal sensation scale. Inside the PMV measurements, +3 interprets as excessively hot, while -3 indicates excessively cold as presented in table 2 , while the range between -0.5 and +0.5 is considered the comfort range. Similar to PMV, PET classify the level of heat stress into nine levels starting from very cold $(<4)$ to very hot (>41). Value between 18 and 23 is considered as comfortable. Meanwhile, UTCI index categorises thermal stress into 10 classes ranging from extreme cold stress $(<-40)$ to extreme heat stress $(>46)$. The numerical threshold for classifying PMV, PET and UTCI are presented in Table 2. In this study, the thermal indices were calculated for a 35 year-old man, $1.75 \mathrm{~m}$ tall, $75 \mathrm{~kg}$ in weight with a metabolic rate 164.49 W/m2 and clothing insulation of $0.9 \mathrm{~m} 2 \mathrm{~K} / \mathrm{W}$.

Table 1. ENVI-met configuration file setting

\begin{tabular}{|c|c|}
\hline Input for configuration file & Value \\
\hline Simulation starting period & 07:00, 20 May 2020 \\
\hline Total simulation time in hours & 24 hrs \\
\hline Save model state (each min) & 60 \\
\hline Wind speed at $10 \mathrm{~m}$ above ground $(\mathrm{m} / \mathrm{s})$ & 3.99 \\
\hline Wind direction & 00 \\
\hline Roughness length & 0.1 \\
\hline Initial temperature atmosphere & $12.2^{\circ} \mathrm{C}$ \\
\hline Relative humidity at $2 \mathrm{~m} \%$ & 82 \\
\hline Factor of short-wave adjustment & 1 \\
\hline Initial temperature, upper layer $(0-20 \mathrm{~cm}$; K) & 293 \\
\hline Initial temperature, middle layer $(20-50 \mathrm{~cm}$; $\mathrm{k})$ & 293 \\
\hline Initial temperature, deep layer $(>50 \mathrm{~cm} ; \mathrm{k})$ & 293 \\
\hline Relative humidity, upper layer & 30 \\
\hline Relative humidity, middle layer & 60 \\
\hline Relative humidity, deep layer & 60 \\
\hline Save receptor (each $\mathrm{min}$ ) & $60 \mathrm{~min}$ \\
\hline Albedo walls & 0.5 \\
\hline Albedo roofs & 0.5 \\
\hline
\end{tabular}

Table 2. Classification of the numerical threshold for thermal indices PMV, PET and UTCI

\begin{tabular}{ccccc}
\hline Thermal & Grade of physiological stress ${ }^{1,2}$ & \multicolumn{3}{c}{ Indices range } \\
\cline { 3 - 5 } perception $^{1}$ & PMV & PET & UTCI \\
\hline Very cold & Extreme cold stress & -3 & $<4$ & $<-40$ \\
\hline Cold & Very strong cold stress & & & -40 to -27 \\
\hline Cool & Strong cold stress & -2.5 & $4-8$ & -27 to -13 \\
\hline Slightly cool & Moderate cold stress & -1.5 & $8-13$ & -13 to 0 \\
\hline & Slight cold stress & -0.5 & $13-$ & 0 to +9 \\
& & & 18 & \\
\hline
\end{tabular}




\begin{tabular}{|c|c|c|c|c|}
\hline Comfortable & No thermal stress & 0 & $\begin{array}{l}18- \\
23\end{array}$ & +9 to +26 \\
\hline Slightly warm & Slightly heat stress & 0.5 & $\begin{array}{c}23- \\
29\end{array}$ & \\
\hline Warm & Moderate heat stress & 1.5 & $\begin{array}{l}29- \\
35\end{array}$ & +26 to +32 \\
\hline Hot & Strong heat stress & 2.5 & $\begin{array}{c}35- \\
41\end{array}$ & +32 to +38 \\
\hline & Very strong heat stress & & & +38 to +46 \\
\hline Very Hot & Extreme heat stress & 3 & $>41$ & $>+46$ \\
\hline
\end{tabular}

${ }^{1} \mathrm{PMV}$ and $\operatorname{PET}\left({ }^{\circ} \mathrm{C}\right){ }^{2} \mathrm{UTCI}\left({ }^{\circ} \mathrm{C}\right)$

\section{Results}

\subsection{ENVI-met model validation}

To validate the ENVI-met performance, numerical simulation was conducted on 10 May 2020. Model validation was performed by comparing air temperature and relative humidity between recorded and simulated values. The parameters that were estimated by the model were agreed with the recorded values and presented in Figure 4 . The $\mathrm{R}^{2}$ value of air temperature and relative humidity was 0.814 and 0.844 respectively; therefore the model was considered reliable in representing the areas studied in this research.

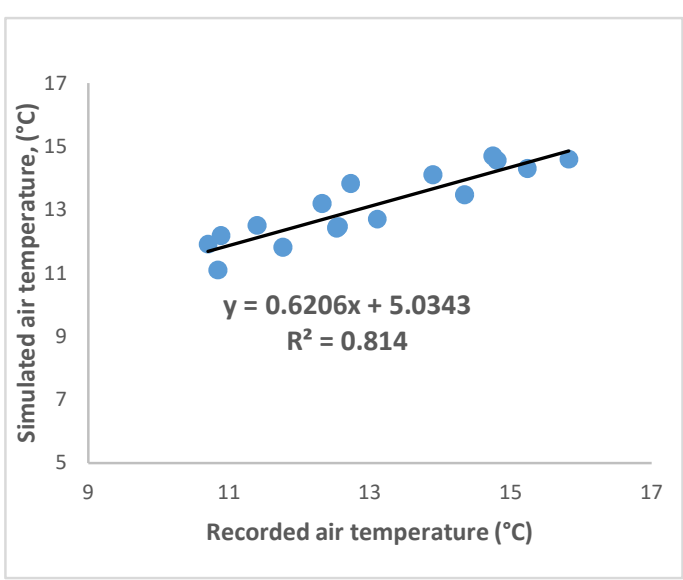

(a)

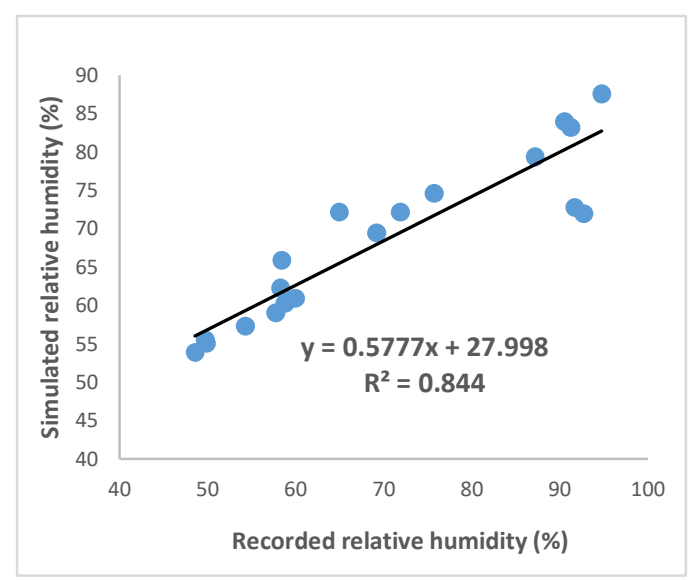

(b)

Figure 4. Regression of recorded vs simulated (a) air temperature (b) relative humidity

\subsection{ENVI-met simulation of air temperature and relative humidity}

After running a 24 hour simulation with an hourly interval, air temperature and relative humidity were extracted. The output of simulation was from 08 am to $23 \mathrm{pm}$. Figures $5 \mathrm{a}$ and $5 \mathrm{c}$ shows that from 09 am to $14 \mathrm{pm}$ the air temperature in both areas gradually increased and then dropped in the afternoon. The high temperatures were between 14-16 pm with the highest temperature in the Treasury Gardens being $14.68{ }^{\circ} \mathrm{C}$ and in the Ibis Melbourne Hotel and Apartments area was $15.66{ }^{\circ} \mathrm{C}$, which means there was $1^{\circ} \mathrm{C}$ difference between the two areas. During the night, the difference in air temperature was relatively small. 
The relative humidity near the Ibis Melbourne Hotel and Apartments ranged between $45.67 \%$ and $86.3 \%$ while in the Treasury Gardens it ranged between $53.95 \%$ and $87.5 \%$. The humidity for both areas in the morning was high and tended to decrease as the day progressed, reaching its lowest point at $3 \mathrm{pm}$ in both areas. From $15 \mathrm{pm}$ to $21 \mathrm{pm}$, relative humidity started to increase gradually and then rose steeply from $21 \mathrm{pm}$ to $23 \mathrm{pm}$ (see Figure $5 \mathrm{~b}$ and $5 \mathrm{~d}$ ).

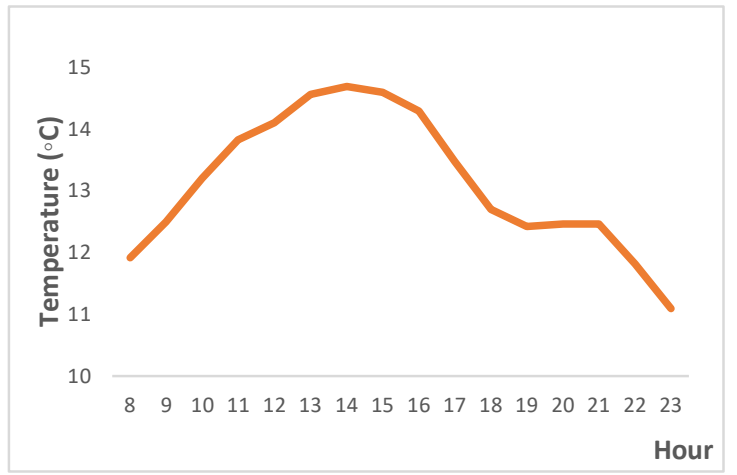

(a)

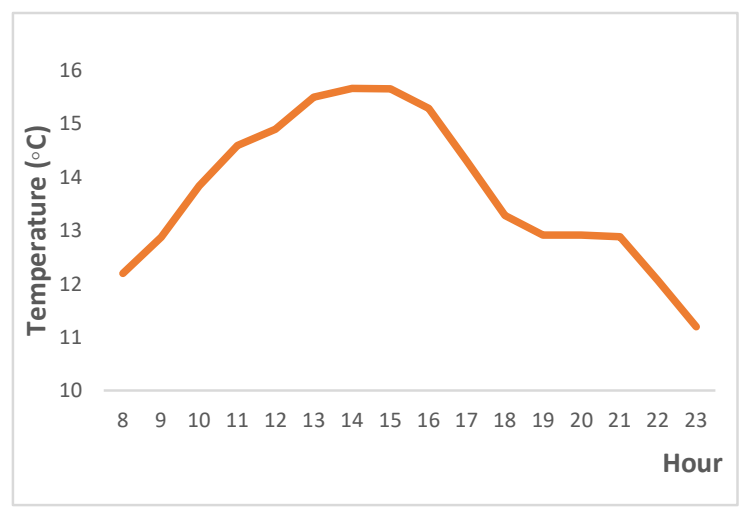

(c)

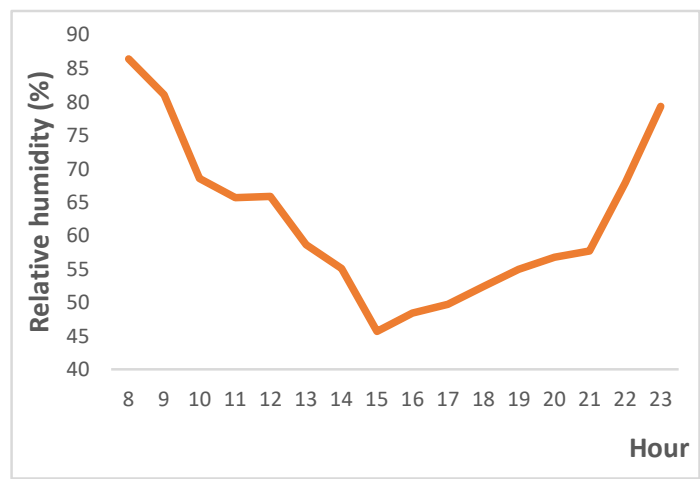

(b)

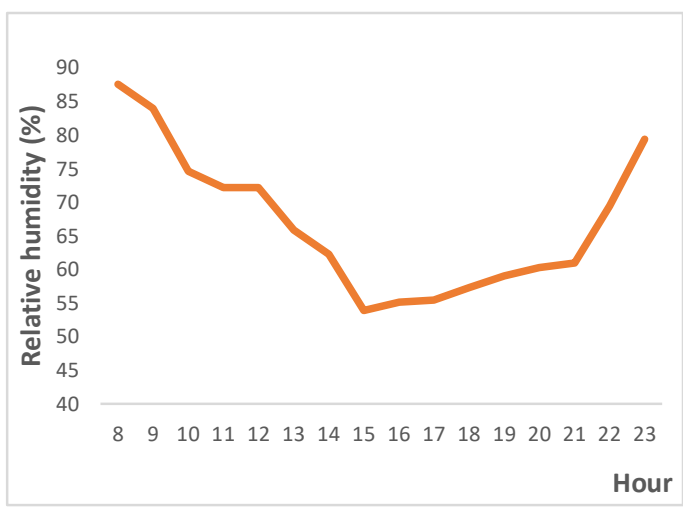

(d)

Figure 5. Air temperature and relative humidity for: (a) \& (b) the Treasury Gardens, (c) \& (d) the Ibis Melbourne Hotel and Apartments area

\subsection{Thermal comfort of garden area}

The microclimate parameter generated from ENVI-met was employed to calculate the value of thermal indices by using ENVI-met BioMet. The Leonardo images show spatial distribution of PMV, PET and UTCI for both the garden area 7 am and $14 \mathrm{pm}$. Figure 6 shows that the PMV at the Treasury Gardens for 7am ranged between - 3.19 and - 2.52. . Based on Frangers' scale, PMV measurements for most areas in the gardens were considered to be cold for the morning. PET at 7 am ranged from $6.27^{\circ} \mathrm{C}-$ $8.95^{\circ} \mathrm{C}$ with the majority part of the area were between $6.80^{\circ} \mathrm{C}-7.10^{\circ} \mathrm{C}$. According to PET scale most of the areas were considered cold and have a strong cold stress level of physiological stress. UTCI map showed the majority of the gardens area was between $3.8^{\circ} \mathrm{C}-5.0^{\circ} \mathrm{C}$ at $7 \mathrm{am}$ with minimum value was $0.28^{\circ} \mathrm{C}$ and the maximum was $10.51^{\circ} \mathrm{C}$. Based on UTCI scale most of the area were considered as slightly cool and in the grade of slight cold stress. Map of PMV, PET and UTCI for the Treasury Gardens at 7 am can be seen in Figure 6, 7, and 8 respectively. 


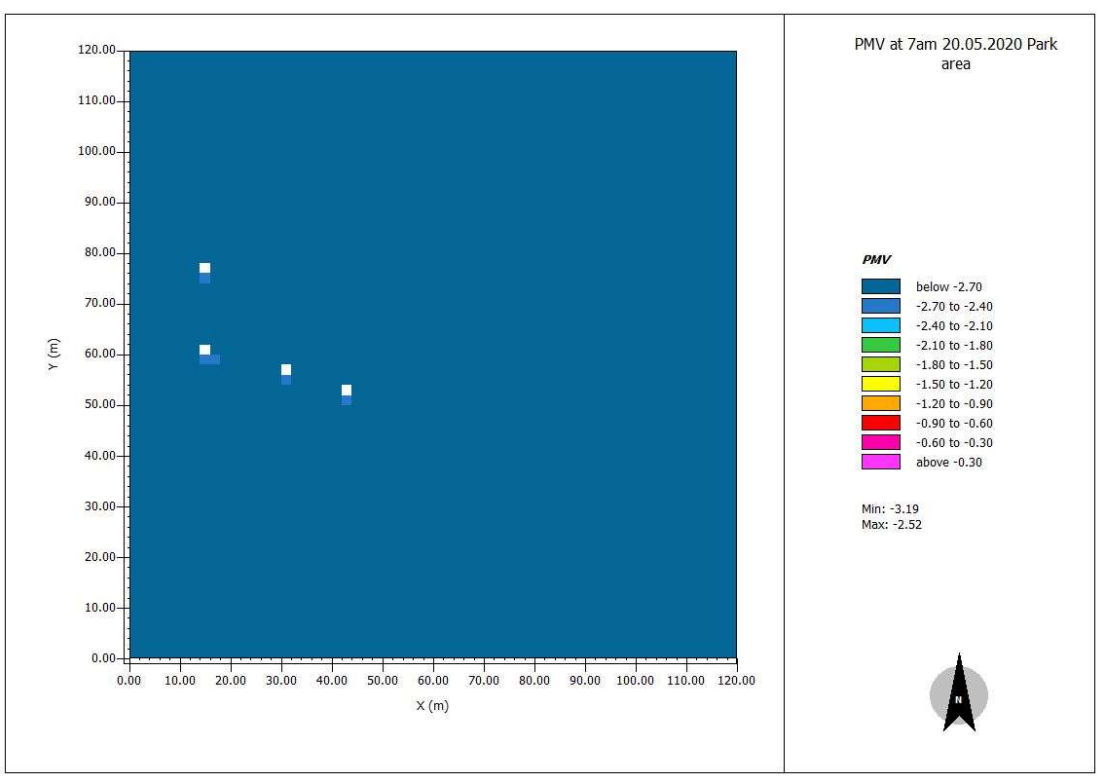

Figure 6. PMV map of the Treasury Gardens at 7 am

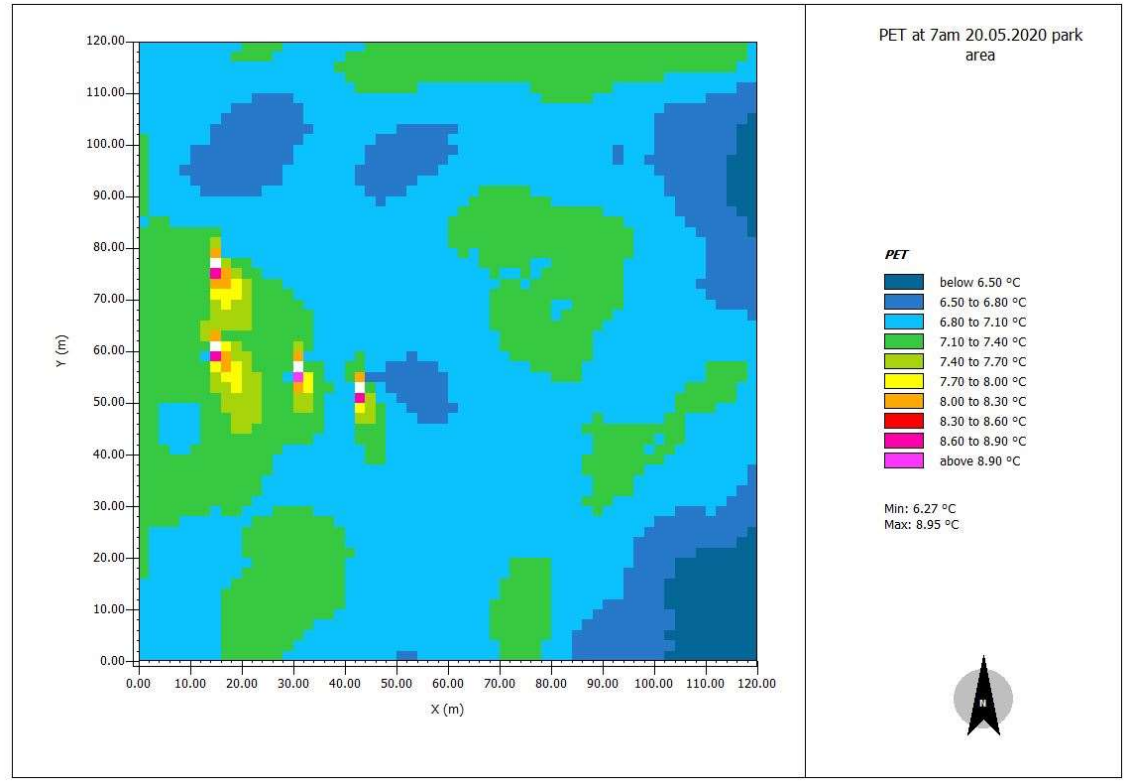

Figure 7. PET map of the Treasury Gardens at 7 am 


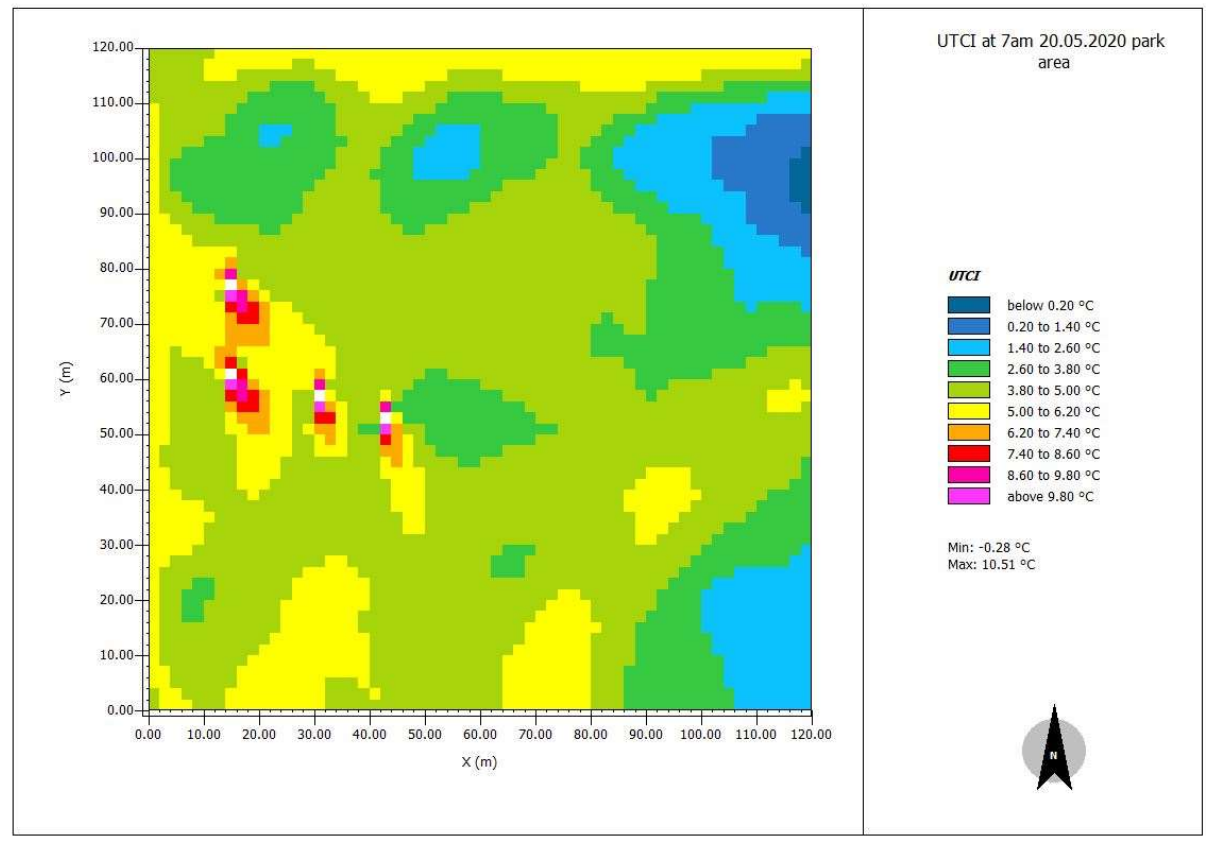

Figure 8. UTCI map of the Treasury Gardens at 7 am

Meanwhile, the PMV for $2 \mathrm{pm}$ ranged between -2.33 and -0.44 with some parts between -2.40 to -2.10 and other parts above -0.33 . The PMV in the afternoon showed that some parts of the Ibis Melbourne Hotel and Apartments area were cool and some were almost comfortable. PET map of the Ibis Melbourne area on $2 \mathrm{pm}$ showed most of the area ranged between $18^{\circ} \mathrm{C}-19.5^{\circ} \mathrm{C}$ and considered to be comfortable. However, in a considerable large area the PET value were between $9.6^{\circ} \mathrm{C}-10.5^{\circ} \mathrm{C}$ and classified as cool and having moderate cold stress. Similarly, UTCI scale showed the large part of the gardens area was between $15.8^{\circ} \mathrm{C}-17.6^{\circ} \mathrm{C}$ and was regarded as comfortable and no thermal stress. In some parts of the Gardens however, the UTCI map described the area as slightly cool as the PET values were ranged between $1.86^{\circ} \mathrm{C}$ to $8.6^{\circ} \mathrm{C}$. It was found that the difference of level of heat stress between morning and afternoon was not significant as these measurements were taken in the early morning and afternoon in late autumn, close to the winter. Map of PMV, PET and UTCI for the Treasury Gardens at 2 pm can be seen in Figure 9, 10 and 11 respectively. 


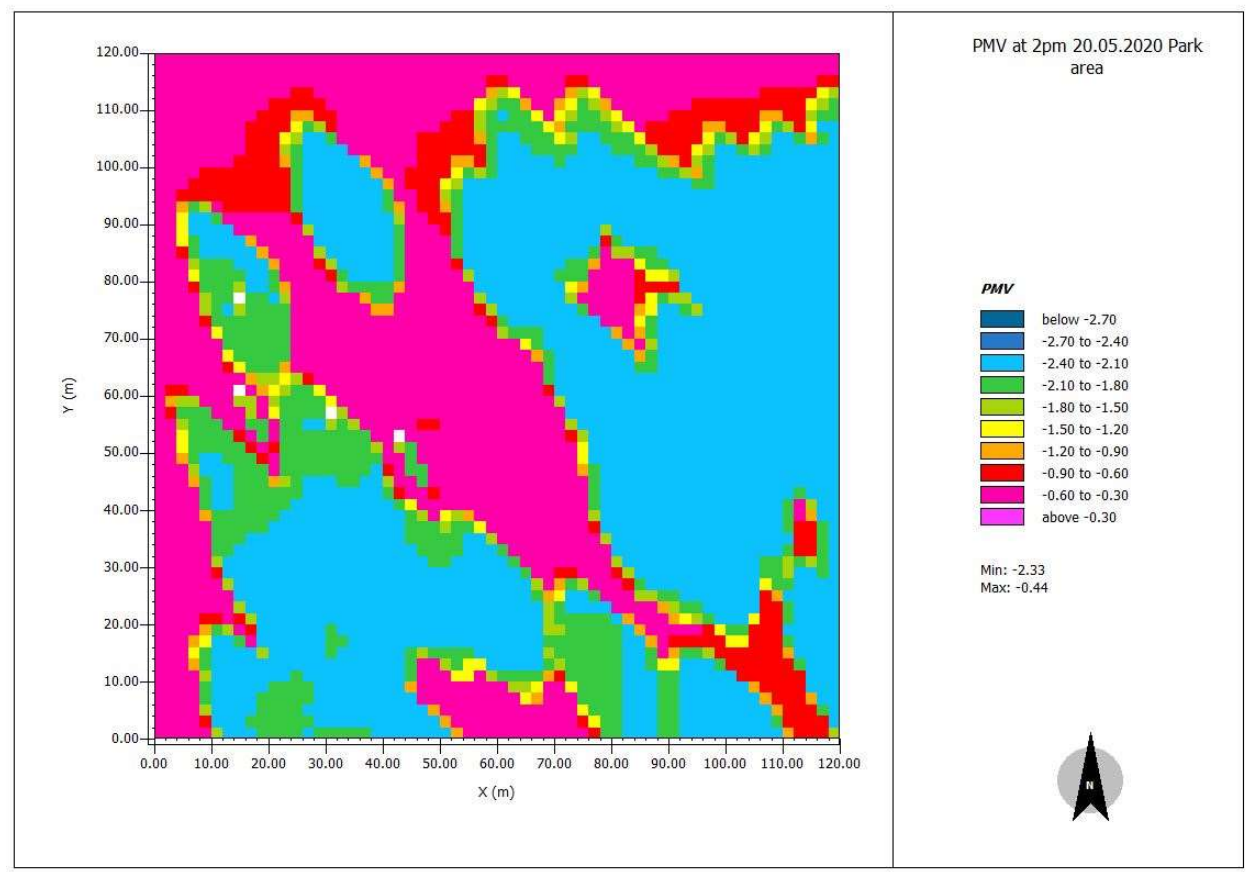

Figure 9. PMV map of the Treasury Gardens at $2 \mathrm{pm}$

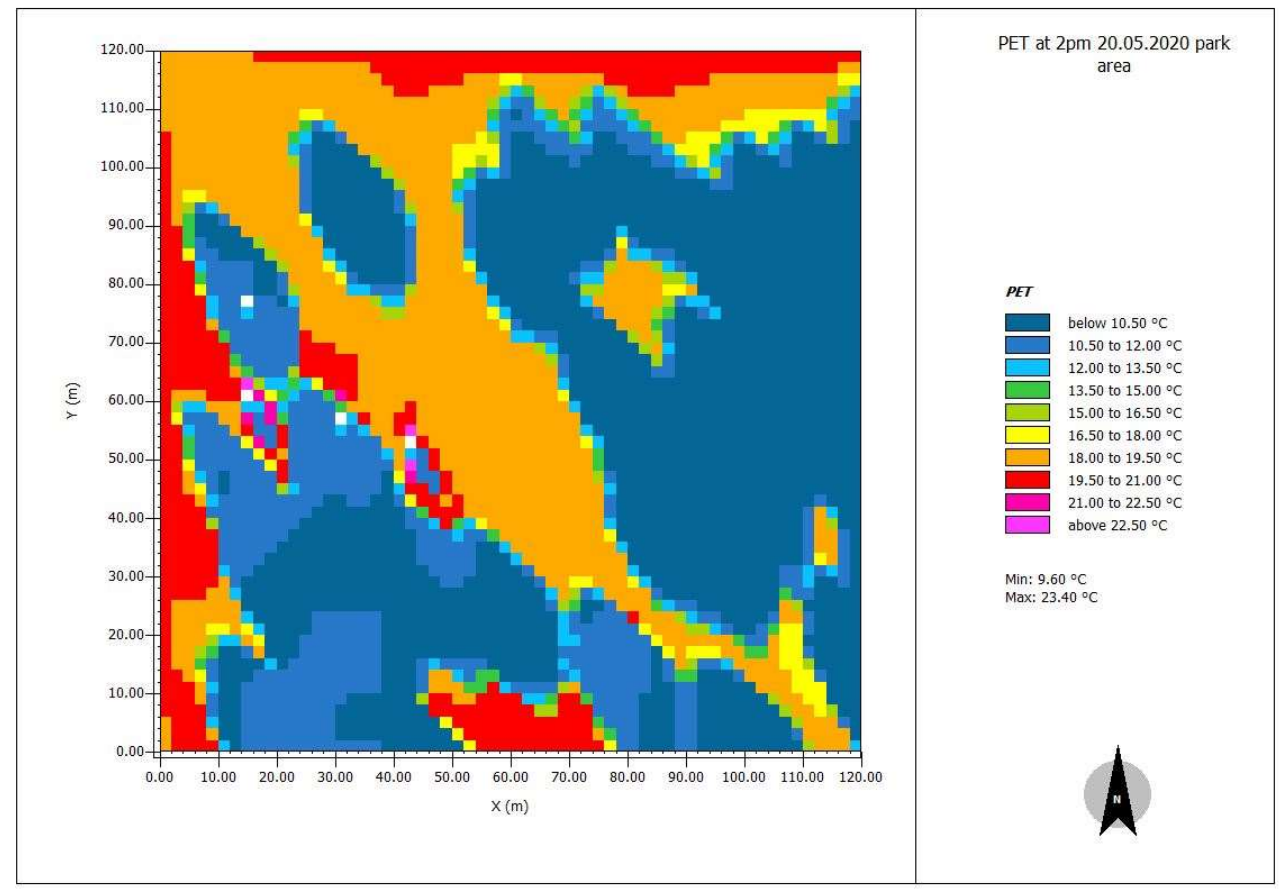

Figure 10. PET map of the Treasury Gardens at $2 \mathrm{pm}$ 


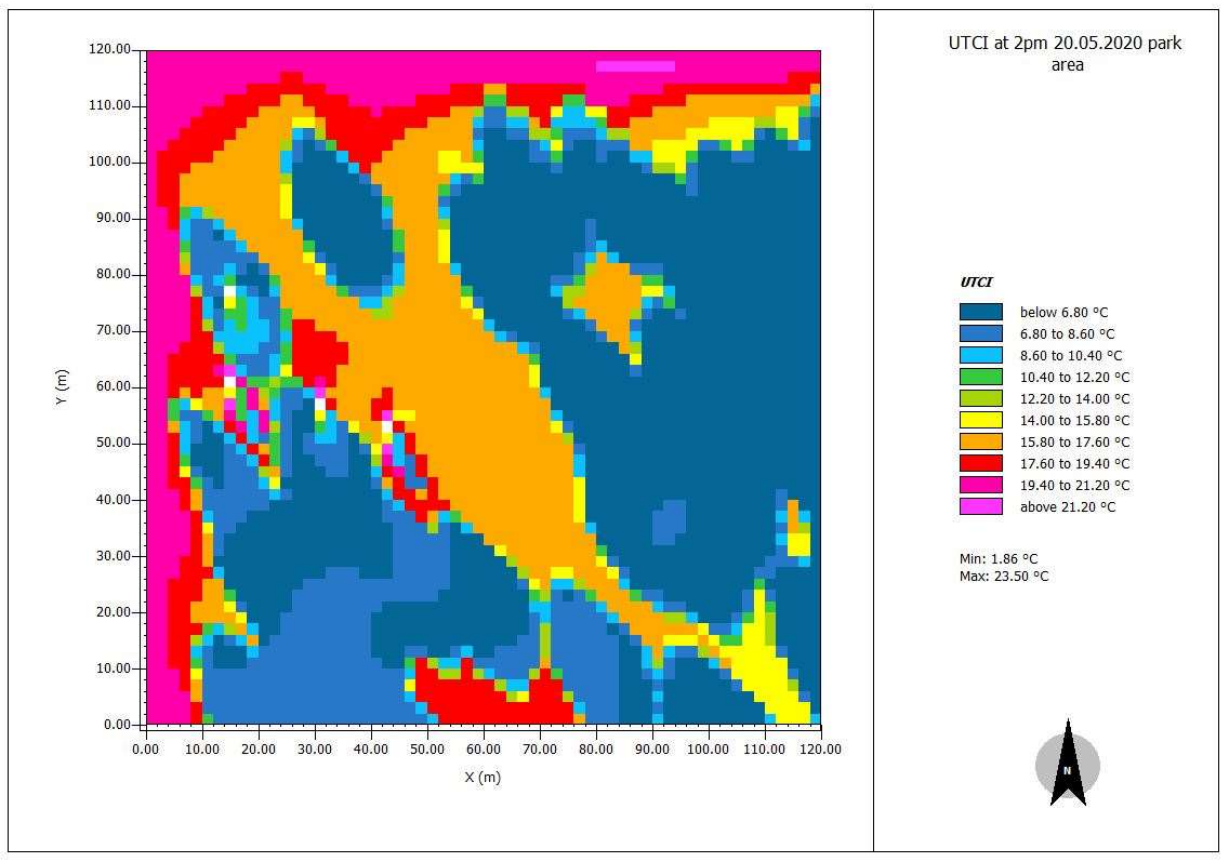

Figure 11. UTCI map of the Treasury Gardens at 2 pm

\subsection{Thermal comfort of building area}

The PMV value in the Ibis Melbourne Hotel and Apartments area ranged between -3.24 and 2.33 for $7 \mathrm{am}$ with the large part of the area were below -2.70 . The value suggested that in the morning the area was considered cold and has a strong cold stress. However, PMV for the area around the buildings was slightly bigger that was -2.40 to -2.10 thus it was classified as cool and has moderate cold stress. Meanwhile PET value for $7 \mathrm{am}$ in the Ibis Melbourne area ranged between $6.10^{\circ} \mathrm{C}-12.39^{\circ} \mathrm{C}$ with the area around the buildings was above $8.90^{\circ} \mathrm{C}$. Based on PET classification, this situation was considered to be cool with moderate cool stress. In some part of the area however, was classified as cold since the PET value was under $8^{\circ} \mathrm{C}$. UTCI value for 7 am were between $-3.49^{\circ} \mathrm{C}$ to $12.20^{\circ} \mathrm{C}$ with the area between the building were mostly above $9^{\circ} \mathrm{C}$ thus it was considered comfortable and no thermal stress.

Based on the simulation, it was found that in the morning, the thermal indices for the area around the building tend to be higher than the other part of the area. This situation made that area has less cold stress and eventually the level of thermal perception went toward comfortable. Spatial distribution of PMV, PET and UTCI at the Ibis Melbourne area are given in Figure 12, 13 and 14 respectively. 


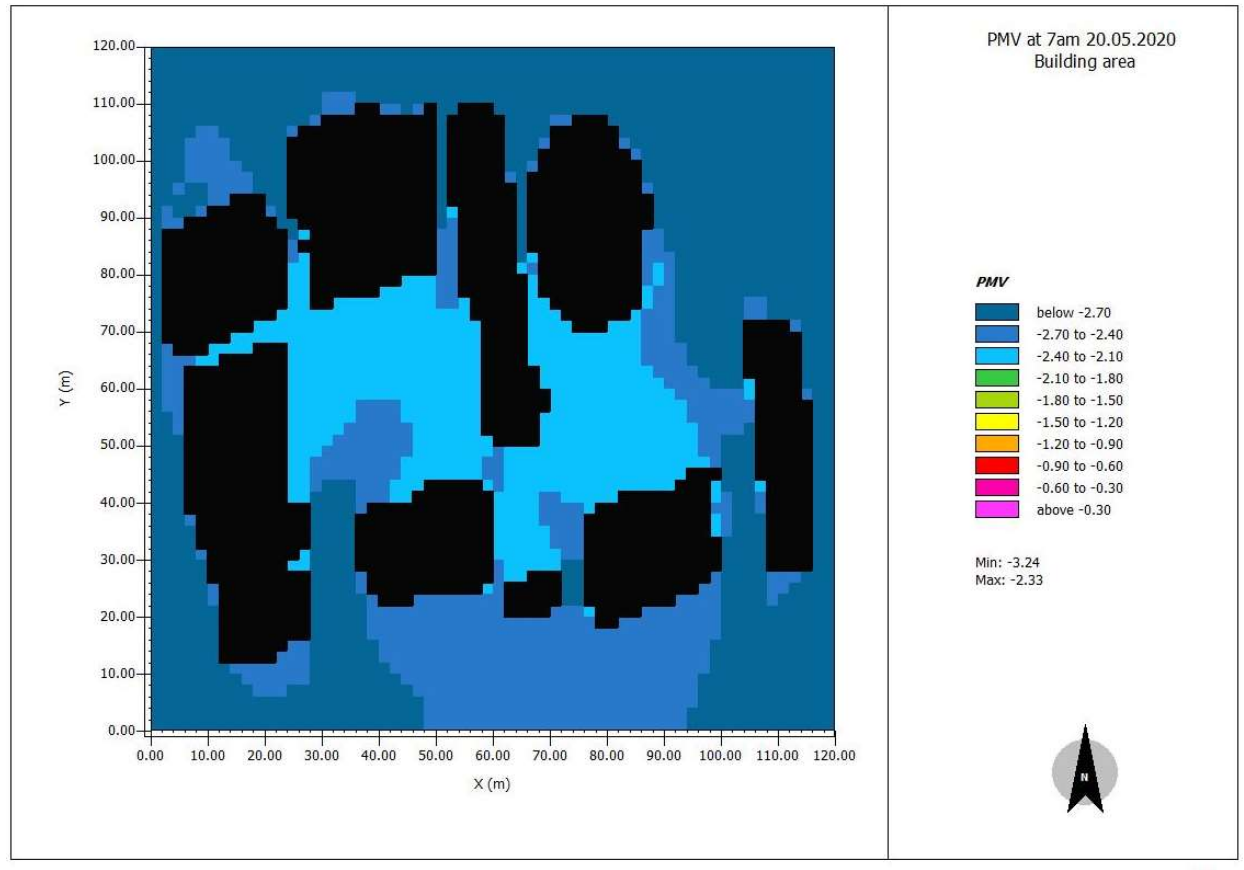

Figure 12. PMV map of the Ibis Melbourne area at 7 am

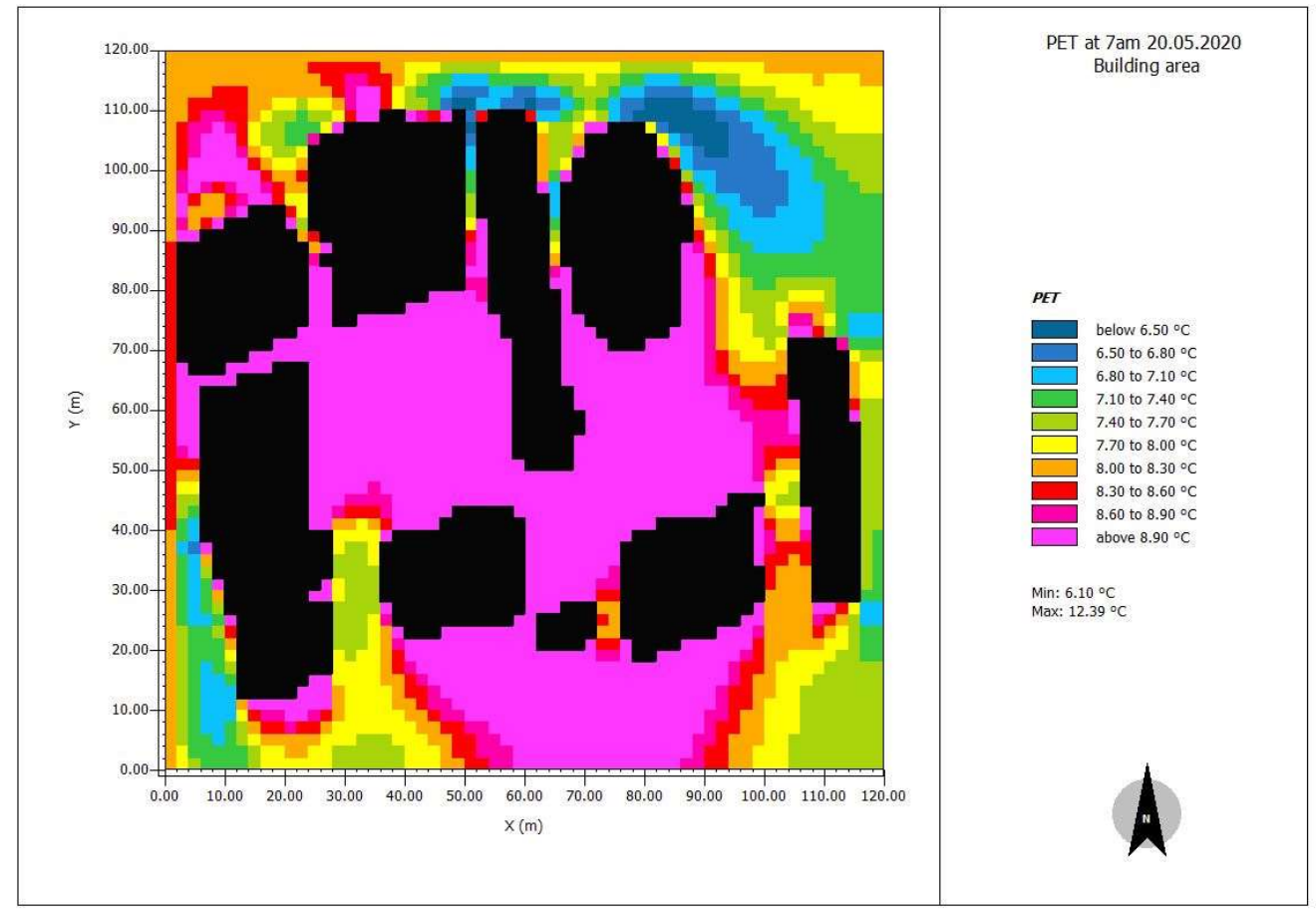

Figure 13. PET map of the Ibis Melbourne area at $7 \mathrm{am}$ 


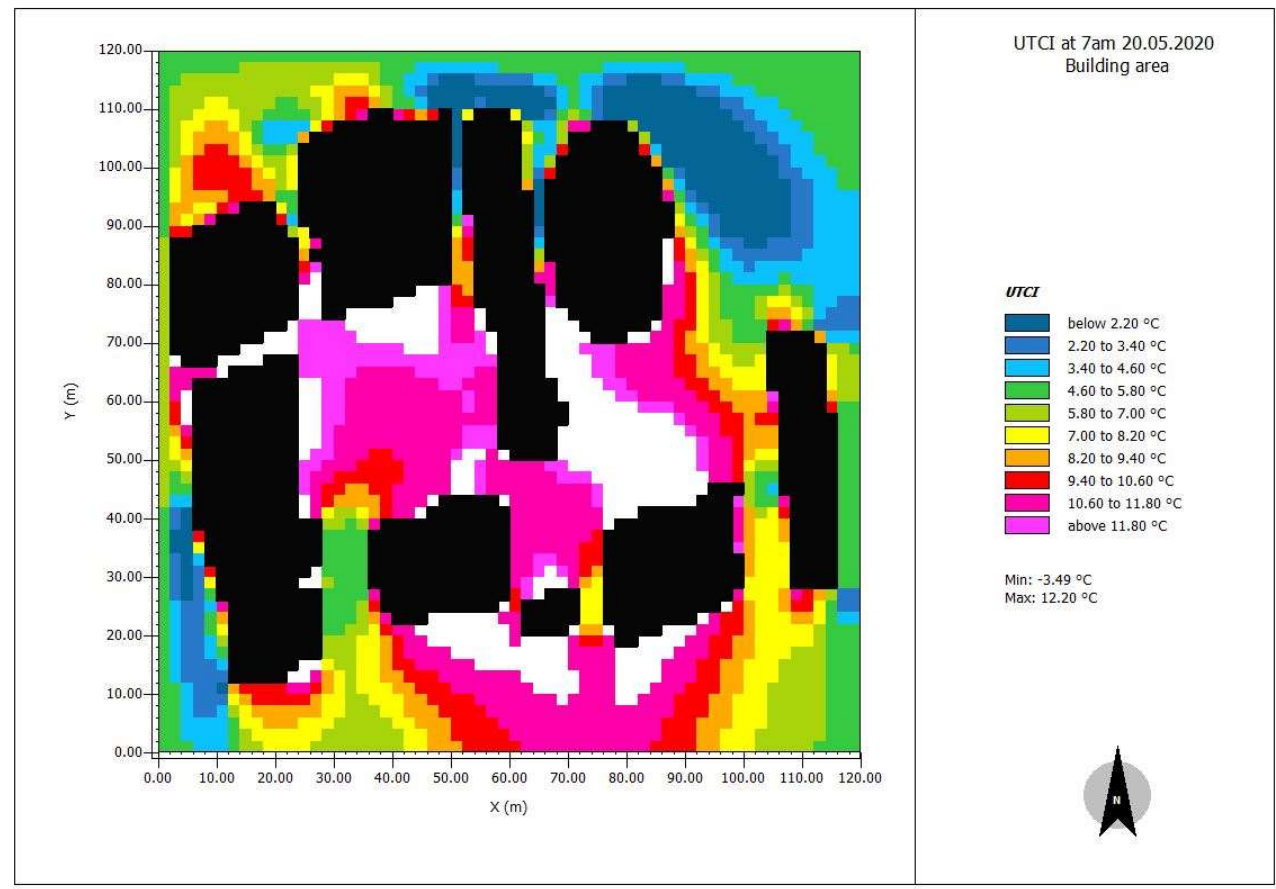

Figure 14. UTCI map of the Ibis Melbourne area at 7 am

PMV for 2 pm ranged between -2.04 and 0.03 with some parts around the buildings were between -1.50 to -1.20 and other parts above -0.33 . The values indicated that some parts of the Ibis Melbourne Hotel and Apartments area were cool and some were almost comfortable. PET map of the Ibis Melbourne area on $2 \mathrm{pm}$ showed that most of the area around the buildings ranged between $15^{\circ} \mathrm{C}$ $21^{\circ} \mathrm{C}$ and considered to be slightly cool as well as comfortable. Maximum PET value occurred on a small area near a building. The area which is marked with red colour in PET map was between $39.0^{\circ} \mathrm{C}-$ $41.3^{\circ} \mathrm{C}$ thus considered as hot and has a strong heat stress. Similarly, UTCI scale showed most of the garden area was between $10.8^{\circ} \mathrm{C}-23^{\circ} \mathrm{C}$ and was regarded as comfortable and no thermal stress. However, in some parts of the area was described as warm and having a moderate heat stress as the UTCI values were above $26^{\circ} \mathrm{C}$. Comparing the difference of level of heat stress during the day, it was found that the difference of level of heat stress between morning and afternoon was not significant. The insignificance occurred as these measurements were taken in the early morning and afternoon in late autumn, close to the winter. Maps of PMV, PET and UTCI for the Ibis Melbourne area at 2 pm are presented in Figure 15, 16, and 17 respectively. In addition, table 3 summarises the thermal indices result from simulation on 20 May 2020 at both the Treasury Gardens and the Ibis Melbourne Hotel and Apartments area. 


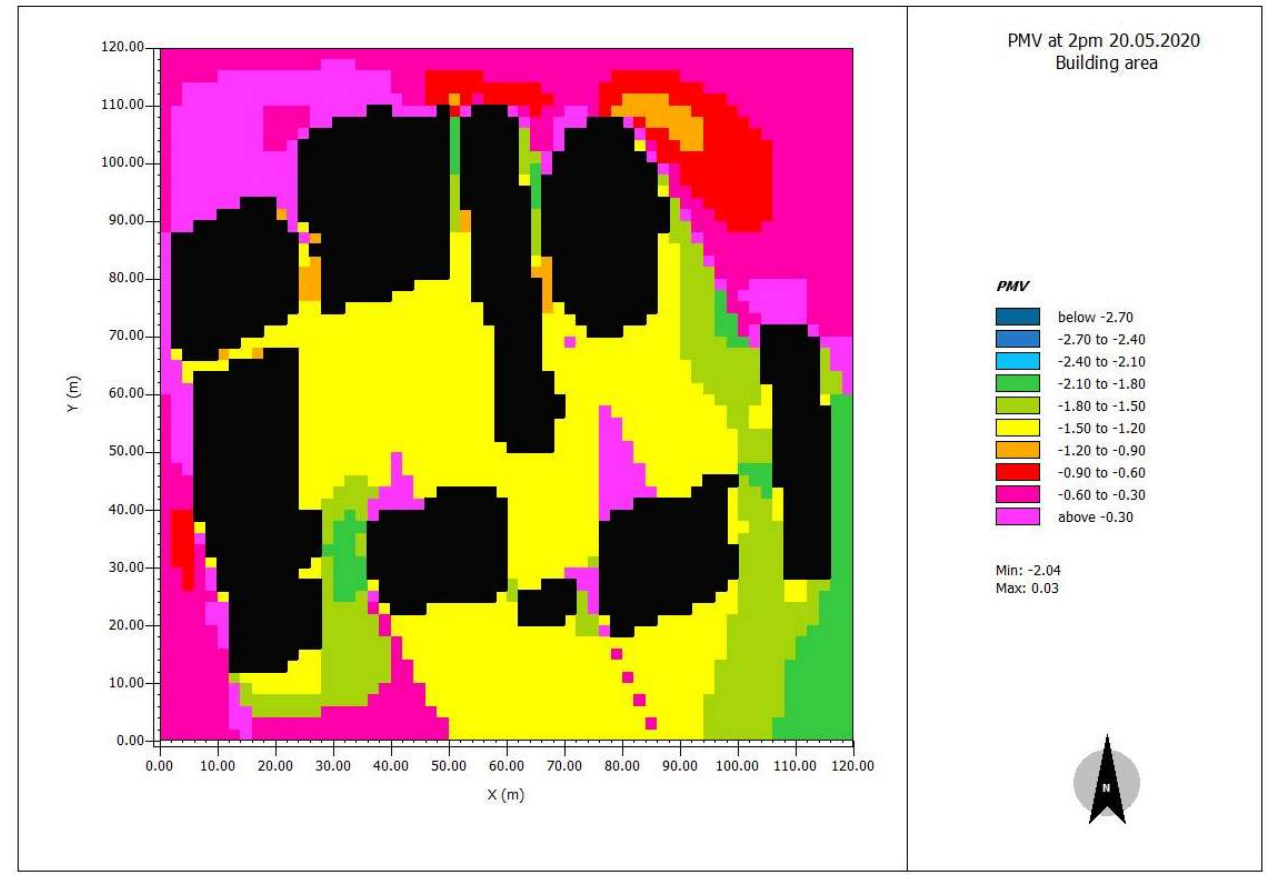

Figure 15. PMV map of the Ibis Melbourne area at $2 \mathrm{pm}$

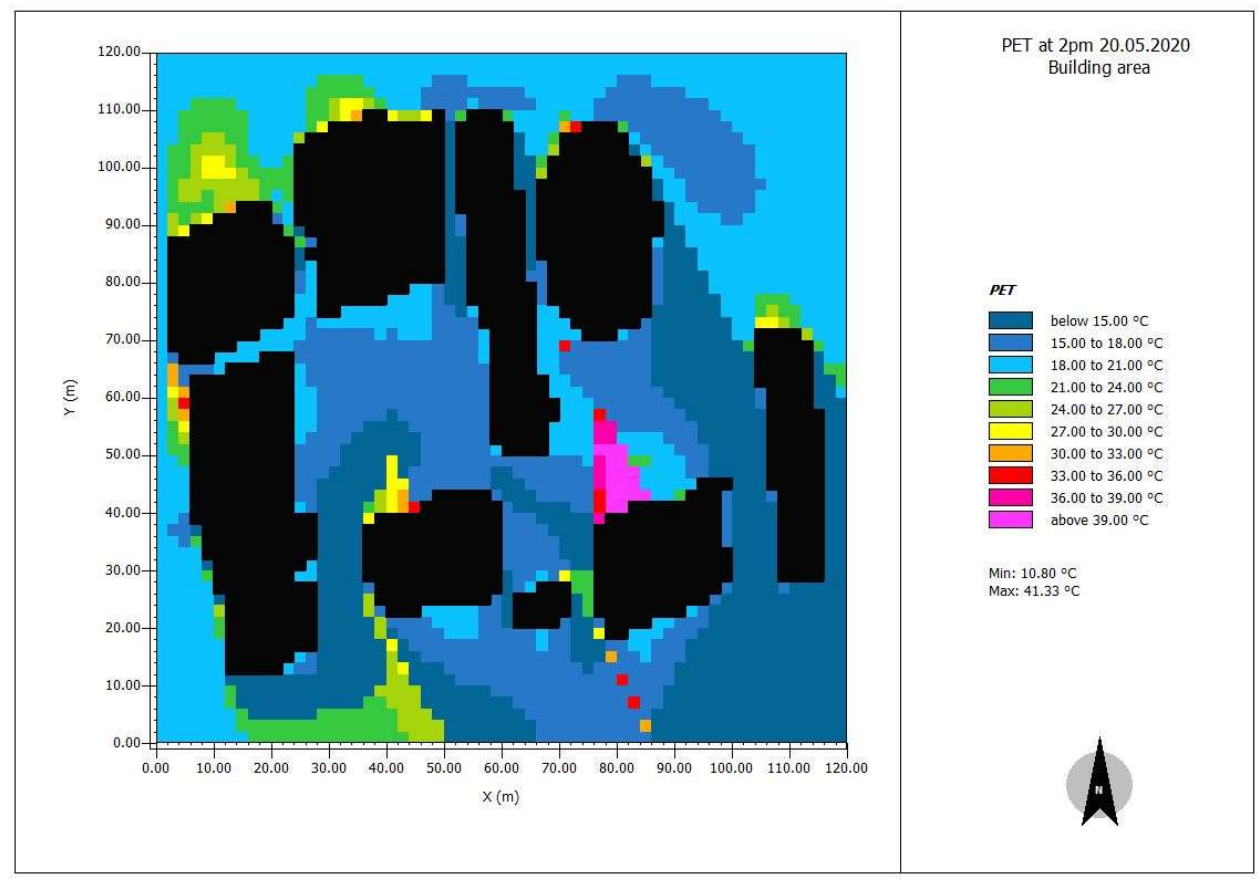

Figure 16. PMV map of the Ibis Melbourne area at $2 \mathrm{pm}$ 


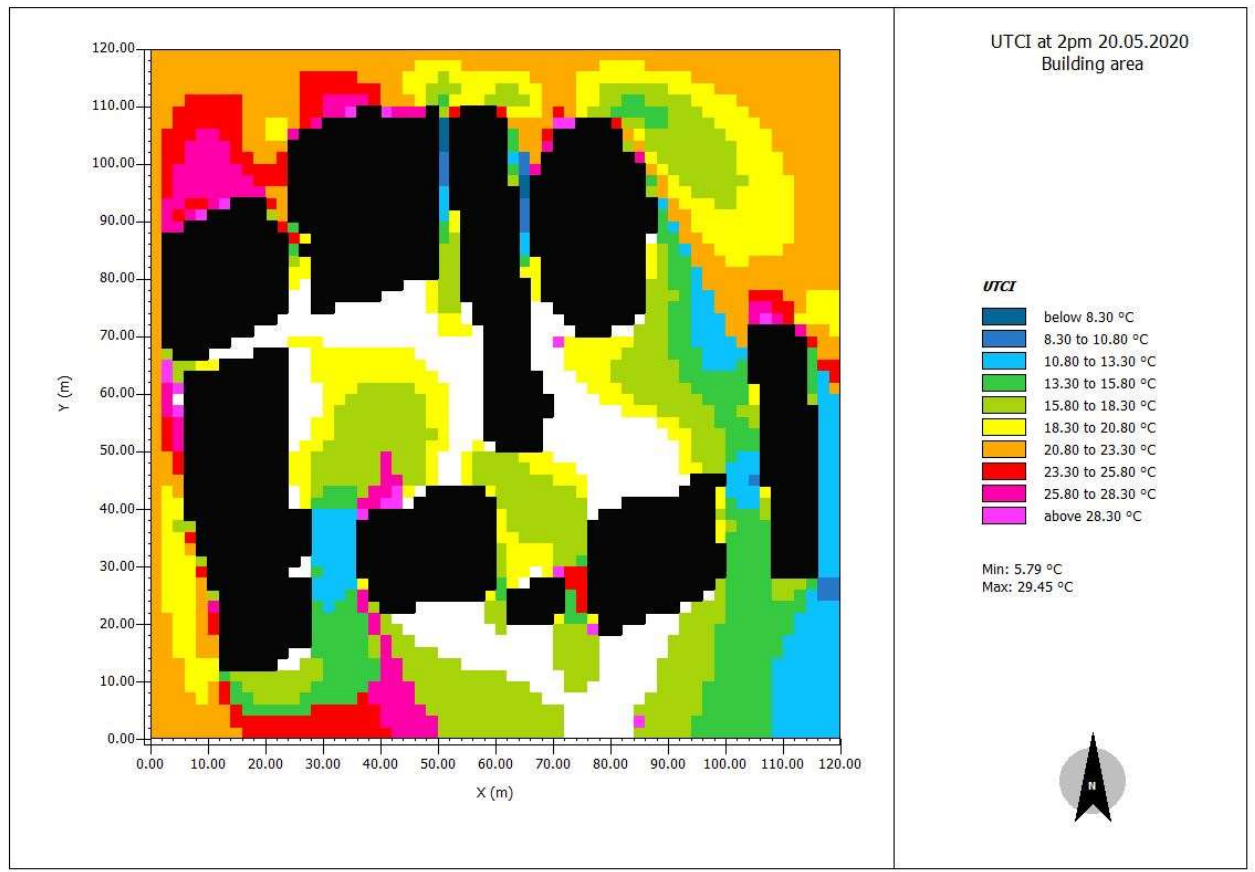

Figure 17. PMV map of the Ibis Melbourne area at $2 \mathrm{pm}$

Table 3. Thermal indices simulation result summary

\begin{tabular}{|c|c|c|c|c|c|c|}
\hline \multirow{3}{*}{ Area } & \multicolumn{6}{|c|}{ Indices Value (min and max) } \\
\hline & \multicolumn{2}{|c|}{ PMV } & \multicolumn{2}{|c|}{ PET } & \multicolumn{2}{|c|}{ UTCI } \\
\hline & 7 am & $2 \mathrm{pm}$ & $7 \mathrm{am}$ & $2 \mathrm{pm}$ & $7 \mathrm{am}$ & $2 \mathrm{pm}$ \\
\hline $\begin{array}{l}\text { The } \\
\text { Treasury } \\
\text { Gardens } \\
\text { (gardens } \\
\text { area) }\end{array}$ & $\begin{array}{c}-3.19 \text { and }- \\
2.52\end{array}$ & $\begin{array}{c}-2.33 \text { and }- \\
0.44\end{array}$ & $\begin{array}{c}6.27^{\circ} \mathrm{C} \text { and } \\
8.95^{\circ} \mathrm{C}\end{array}$ & $\begin{array}{c}9.60^{\circ} \mathrm{C} \text { and } \\
23.40^{\circ} \mathrm{C}\end{array}$ & $\begin{array}{c}-0.28^{\circ} \mathrm{C} \text { and } \\
10.51^{\circ} \mathrm{C}\end{array}$ & $\begin{array}{c}1.86^{\circ} \mathrm{C} \text { and } \\
23.50^{\circ} \mathrm{C}\end{array}$ \\
\hline $\begin{array}{l}\text { The Ibis } \\
\text { Melbourne } \\
\text { (building } \\
\text { area) }\end{array}$ & $\begin{array}{c}-3.24 \text { and - } \\
2.33\end{array}$ & $\begin{array}{c}-2.04 \text { and } \\
0.03\end{array}$ & $\begin{array}{c}6.10^{\circ} \mathrm{C} \text { and } \\
12.39^{\circ} \mathrm{C}\end{array}$ & $\begin{array}{c}10.80^{\circ} \mathrm{C} \text { and } \\
41.33^{\circ} \mathrm{C}\end{array}$ & $\begin{array}{c}-3.49^{\circ} \mathrm{C} \text { and } \\
12.20^{\circ} \mathrm{C}\end{array}$ & $\begin{array}{c}5.79^{\circ} \mathrm{C} \text { and } \\
29.45^{\circ} \mathrm{C}\end{array}$ \\
\hline
\end{tabular}

\section{Discussion}

The purpose of this paper is to study how the difference between thermal comforts levels in a vegetated area and a high-rise building area by taking two samples from each area. In this study, numerical simulation using ENVI-met version 4 was conducted in an urban garden and a building area. It was found that the temperature in the garden area was lower by approximately $1^{\circ} \mathrm{C}$ than the building area at $2 \mathrm{pm}$ (the hottest hour of the day). As the temperature decreases, the level of thermal comfort will change.

Thermal comfort at the Treasury Garden at 7 am showed similar result for PMV and PET. The indices indicated that most of the garden area at 7 am was categorised as cold, while UTCI index showed that the area mostly under slightly cool thermal perception thus having slight cold stress. In the afternoon $(2 \mathrm{pm})$ all the indices classified the garden area as comfortable and having no thermal 
stress although small parts of the areas were cool under PMV and PET classification. Simulation result at the Ibis Melbourne area in the morning and afternoon showed more mixed results. At 7 am in the morning, PMV and PET categorised the area as cold and cool respectively although thermal perception for the area around the building has one class warmer that are cool and comfortable for PMV and PET respectively. Under UTCI classification, the area was comfortable and having no thermal stress. PMV simulated the Ibis Melbourne area in the afternoon $(2 \mathrm{pm})$ as cool except for the areas around the buildings which was comfortable. This result is similar to PET where the area was categorised as slightly cool and comfortable. However, some parts which are marked by red colour were under hot thermal perception and have a strong heat stress level. This was happened due to the wind speed at those areas were very low which lead increasing the level of heat stress. Unlike the gardens, the Ibis Melbourne area is not an open area and there is only low vegetation between the high-rise buildings which makes it hard for the wind to move freely. Wind speed is one important factor affecting human thermal comfort. It can enhance the heat transfer between human body and the surrounding environment as well as increase the draft sensation [41]. Under UTCI classification most of the Ibis Melbourne area were under comfortable thermal perception. However, during simulation for building area it was found in several parts without UTCI values. These areas were marked as white colour (see Figure 14 and 17). The very low wind speed (lower than $0.5 \mathrm{~m} / \mathrm{s}$ ) on the areas made UTCI was unable to calculate its value thus. In order to calculate UTCI the wind speed should range from 0.5 to $17 \mathrm{~m} / \mathrm{s}$ [42].

In this study the simulation was conducted during the late autumn toward winter. Increasing temperatures at midday led to a change in the level of thermal comfort for both the building and the gardens area even though it was not significant. The difference in the level of thermal comfort during the day might be obvious if the simulation was conducted during the summer. It is also found that in general the thermal perception in the Treasury Gardens area was slightly 'cooler' than the Ibis Hotel and Apartments area. It is because of the presence of vegetation which can lower the temperature and eventually influence thermal comfort its surrounding area.

\section{Conclusions}

This paper studied the potential of GI to mitigate human heat stress in the CBD area of Melbourne, Australia. The three-dimension meteorological model ENVI-met was used to simulate two different scenarios of a public garden area and a high-rise building area. The PMV, PET and UTCI indices were used to assess the level of heat stress based on microclimate in the research area. The results showed that the garden area had a lower temperature than the high-rise building area by approximately $1{ }^{\circ} \mathrm{C}$ during the hottest hour of the day. However, the level of thermal comfort did not show a significant difference between the areas. The outcome of the study highlighted the important role of GI in reducing temperature and creating a thermally comfortable outdoor environment for urban dwellers.

In this study the GI modelled were only represented by a small range of plants. Therefore, it would be beneficial for future work to incorporate a wide range of plants to assess the potential of various vegetation towards UHI mitigation. Such knowledge would help urban planners to select effective types of vegetation in order to mitigate the effect of UHI.

\section{References}

1. Johansson, E.; Yahia, M, Editors. 387: Improving outdoor thermal comfort in warm-humid Guayaquil, Ecuador through urban design. ICUC8-8th International Conference on Urban Climates (ICUC8), 2012.

2. Aflaki, A.; Mirnezhad, M.; Ghaffarianhoseini, A.; Ghaffarianhoseini, A.; Omrany, H.; Wang ZH.; et al. Urban heat island mitigation strategies: A state-of-the-art review on Kuala Lumpur, Singapore and Hong Kong. Cities. 2017, 62, 131-145. 
3. Alexandri, E.; Jones, P. Temperature decreases in an urban canyon due to green walls and green roofs in diverse climates. Build. Environ. 2008, 43(4), 480-493.

4. Morakinyo, T.E.; Lam,Y.F. Simulation study on the impact of tree-configuration, planting pattern and wind condition on street-canyon's micro-climate and thermal comfort. Build. Environ. 2016, 103, 262-275.

5. Perini, K.; Magliocco, A. Effects of vegetation, urban density, building height, and atmospheric conditions on local temperatures and thermal comfort. Urban For. Urban Green. 2014, 13(3), 495 506.

6. Emmanuel, R.; Loconsole, A. Green infrastructure as an adaptation approach to tackling urban overheating in the Glasgow Clyde Valley Region, UK. Landsc. Urban Plan. 2015, 138, 71-86.

7. Lee, H.; Mayer, H.; Chen, L. Contribution of trees and grasslands to the mitigation of human heat stress in a residential district of Freiburg, Southwest Germany. Landsc. Urban Plan. 2016, 148, 37-50.

8. D'Sousa, U. Measuring green roof performance, a solution to sustainable urban development in the UEA. Int. J. Sust Develop Plan. 2014, 9(3), 376-388.

9. Feyisa, G.L.; Dons, K.; Meilby, H. Efficiency of gardens in mitigating urban heat island effect: An example from Addis Ababa. Landsc. Urban Plan. 2014, 123, 87-95.

10. Georgi, N.J.; Zafiriadis, K. The impact of garden trees on microclimate in urban areas. Urban Ecosys. 2006, 9(3), 195-209.

11. Razzaghmanesh, M.; Beecham, S.; Salemi, T. The role of green roofs in mitigating Urban Heat Island effects in the metropolitan area of Adelaide, South Australia. Urban For. Urban Green. 2016, 15, 89-102.

12. Jamei, E.; Rajagopalan, P. Urban development and pedestrian thermal comfort in Melbourne. Sol. Energy. 2017, 144, 681-698.

13. Rui, L.; Buccolieri, R.; Gao, Z.; Gatto, E.; Ding, W, Editors. Study of the effect of green quantity and structure on thermal comfort and air quality in an urban-like residential district by ENVImet modelling. Build. Simul. 2019, 12, 183-194.

14. Afshar, N.K.; Karimian, Z.; Doostan, R.; Nokhandan, M.H. Influence of planting designs on winter thermal comfort in an urban garden. J. Environ. Eng. Landsc. Manage. 2018, 26(3), 232240 .

15. Al-hagla, K.S.; El-sayad, Z.T. Using simulation methods to investigate the impact of urban form on human comfort. Case study: Coast of Baltim, North Coast, Egypt. Alexand. Eng. J. 2019, 58(1), 273-282.

16. Ali-Toudert, F.; Mayer H. Numerical study on the effects of aspect ratio and orientation of an urban street canyon on outdoor thermal comfort in hot and dry climate. Build. Environ. 2006, 41(2), 94-108.

17. Hirashima, S.S.; Katzschner, A.; Ferreira, D.G.; De Assis E.; Katzschner, L. Thermal comfort comparison and evaluation in different climates. Urban Clim. 2018, 23, 219-251.

18. Karakounos, I.; Dimoudi, A.; Zoras, S. The influence of bioclimatic urban redevelopment on outdoor thermal comfort. Energy Build. 2018, 158, 1266-1274.

19. Kamar, H.M.; Kamsah, N.; Ghaleb, F.; Alhamid, M.I. Enhancement of thermal comfort in a large space building. Alexand. Eng. J. 2019, 58(1), 49-65.

20. Katafygiotou, M.C.; Serghides, D.K. Thermal comfort of a typical secondary school building in Cyprus. Sustain. Cities Soc. 2014, 13, 303-312.

21. Klemm, W.; Heusinkveld, B.G.; Lenzholzer, S.; van Hove, B. Street greenery and its physical and psychological impact on thermal comfort. Landsc. Urban Plan. 2015, 138, 87-98.

22. Kong, L.; Lau, KK-L.; Yuan, C.; Chen, Y.; Xu, Y.; Ren, C.; et al. Regulation of outdoor thermal comfort by trees in Hong Kong. Sustain. Cities Soc. 2017, 31, 12-25.

23. Manat Srivanit, K.H. Evaluating the cooling effects of greening for improving the outdoor thermal environment at an institutional campus in the summer. Build. Environ. 2013, 66. 
24. Blazejczyk, K.; Epstein, Y.; Jendritzky, G.; Staiger, H.; Tinz, B. Comparison of UTCI to selected thermal indices. Int. J. Biometeorol. 2012, 56(3), 515-535.

25. Johansson, E.; Thorsson, S.; Emmanuel, R.; Krüger, E. Instruments and methods in outdoor thermal comfort studies-The need for standardization. Urban Clim. 2014, 10, 346-366.

26. Fanger, P.O. Thermal comfort. Analysis and applications in environmental engineering. Thermal comfort Analysis and applications in environmental engineering. 1970.

27. Höppe, P. The physiological equivalent temperature-a universal index for the biometeorological assessment of the thermal environment. Int. J. Biometeorol. 1999, 43(2), 71-75.

28. Bröde, P.; Fiala, D.; Błażejczyk, K.; Holmér, I.; Jendritzky, G.; Kampmann, B.; et al. Deriving the operational procedure for the Universal Thermal Climate Index (UTCI). Int. J. Biometeorol. 2012, 56(3), 481-494.

29. Fiala, D.; Havenith, G.; Bröde, P.; Kampmann, B.; Jendritzky, G. UTCI-Fiala multi-node model of human heat transfer and temperature regulation. Int. J. Biometeorol. 2012, 56(3), 429-441.

30. Jendritzky, G.; Maarouf, A.; Staiger, H, Editors. Looking for a universal thermal climate index (UTCI) for outdoor applications. Windsor-conference on thermal standards. 2001.

31. Gagge, A.P.; Fobelets, A.; Berglund, L. A standard predictive Index of human reponse to thermal enviroment. Transac./American Soc. Heat, Ref. Air-Cond. Eng. 1986, 92(2B), 709-731.

32. Dain, J. Validation of ENVI-met PMV values by in-situ measurements. 2015.

33. Müller, N.; Kuttler, W.; Barlag, A-B. Counteracting urban climate change: adaptation measures and their effect on thermal comfort. Theor. Appl. Climatol. 2014, 115(1-2), 243-257.

34. Błażejczyk, K. New climatological and physiological model of the Human Heat Balance outdoor (MENEX) and its applications in bioclimatological studies in different scales. Zeszyty Instytutu Geografii i Przestrzennego Zagospodarowania PAN. 1994(28), 27-58.

35. Yu, C.; Hien, W.N. Thermal benefits of city gardens. Energy Build. 2006, 38(2), 105-120.

36. Hwang, Y.H.; Lum, Q.J.G.; Chan, Y.K.D. Micro-scale thermal performance of tropical urban gardens in Singapore. Build. Environ. 2015, 94, 467-76.

37. Lin, B-S.; Lin, C-T. Preliminary study of the influence of the spatial arrangement of urban gardens on local temperature reduction. Urban For. Urban Green. 2016, 20, 348-357.

38. Bruse, M.; Fleer, H. Simulating surface-plant-air interactions inside urban environments with a three dimensional numerical model. Environ. Mod. Soft. 1998, 13(3-4), 373-384.

39. Bruse, M. Using ENVI-met BioMet. ENVI-met. 2014, 12.

40. Chatzinikolaou, E.; Chalkias, C.; Dimopoulou, E. Urban microclimate improvment using ENVI-met climate model. Int. Arc. Photo, Rem. Sens. Spat Info Sci. 2018, 42(4).

41. Hou, Y, editor Effect of wind speed on human thermal sensation and thermal comfort. AIP Conference Proceedings, 2018, AIP Publishing LLC.

42. Froehlich, D.; Matzarakis, A, editors. Estimation of human-biometeorological conditions in south west Germany for the assessment of mitigation and adaptation potential. ICUC9-9th international conference on urban climate jointly with 12th symposium on the urban environment, 2015. 